\title{
Chlorpromazine Combined with Cidofovir for Treatment of a Patient Suffering from Progressive Multifocal Leukoencephalopathy
}

\author{
Christoph Pöhlmann $^{a} \quad$ Kristina Hochaufa Christoph Röllig $^{c}$ \\ Johannes Schetelig ${ }^{c}$ Olaf Wunderlich ${ }^{d}$ Dirk Bandt $^{b}$ Gerhard Ehninger ${ }^{c}$ \\ Enno Jacobs $^{a}$ Jacques Rohayem ${ }^{b}$ \\ ${ }^{\mathrm{a}}$ Institut für medizinische Mikrobiologie und Hygiene, ${ }^{\mathrm{b}}$ Institut für Virologie, ${ }^{\mathrm{c}}$ Medizinische Klinik und \\ Poliklinik I und ${ }^{\mathrm{d}}$ Institut und Poliklinik für Radiologische Diagnostik, Universitätsklinikum Carl Gustav Carus, \\ Technische Universität, Dresden, Deutschland
}

\section{Key Words}

JC viral load • Progressive multifocal leukoencephalopathy • Cidofovir · Chlorpromazine

\begin{abstract}
We report on a stem cell-transplanted patient with B cell chronic lymphatic leukemia who presented with a subacute onset of focal neurological deficits, gait abnormalities, emotional lability and dementia. Progressive multifocal leukoencephalopathy was diagnosed by magnetic resonance imaging (MRI) of the brain and detection of JC virus genome in the cerebrospinal fluid. Cidofovir and the $5 \mathrm{HT} 2 \mathrm{~A}$ receptor antagonist chlorpromazine were subsequently administered. A follow-up MRI of the brain 2 weeks after initiation of the antiviral therapy displayed progress of the demyelination, and the patient died 3 months after onset of the neurological symptoms. This report highlights the need for the development of novel and potent strategies for treatment of progressive multifocal leukoencephalopathy.
\end{abstract}

Copyright @ 2008 S. Karger AG, Basel

C.P. and K.H. contributed equally to this work.

\section{Case Report}

A 58-year-old human immunodeficiency virus (HIV)negative man was diagnosed with $\mathrm{B}$ cell chronic lymphatic leukemia (CLL) of Binet stage C in 1995. In 2002, disease progression necessitated the administration of $6 \mathrm{cy}$ cles of fludarabine (FAMP; table 1). The patient's health status deteriorated in October 2003, and chemotherapy was altered to the CHOP 21 regimen (doxorubicin, cyclophosphamide, vincristine and prednisone; table 1). Treatment was discontinued after 3 cycles due to unresponsiveness. After 2 relapses of B cell CLL, complete remission was achieved by treatment with alemtuzumab (table 1). The patient was subsequently referred for HLADR mismatched allogeneic stem cell transplantation (SCT) in late January 2004. Reduced-intensity conditioning consisted of FAMP, busulfan and alemtuzumab (table 1). Graft-versus-host disease (GvHD) prophylaxis was initially carried out with cyclosporin A, but was switched to tacrolimus due to side effects (table 1). Twelve days after SCT the patient developed acute skin GvHD, which responded to prednisolone therapy. On day 40 after SCT, cytomegalovirus reactivation occurred (pp65 antigenemia: 2 positive cells/100,000 leukocytes) and was successfully treated by valganciclovir medication for 5 weeks.

Jacques Rohayem

Institut für Virologie

Fiedlerstrasse 42

DE-01307 Dresden (Germany)

Tel. +49351 458 6200, Fax +49351 458 6310, E-Mail jacques.rohayem@tu-dresden.de

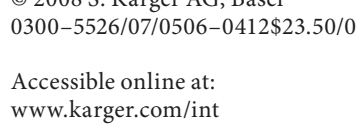


Table 1. Posology and time of administration of the drugs in the course of the patient's stem cell transplantation

\begin{tabular}{|c|c|c|}
\hline Drug & Posology ${ }^{1}$ & $\begin{array}{l}\text { Year/time period } \\
\text { relative to } \mathrm{SCT}^{2}\end{array}$ \\
\hline Fludarabine & $25 \mathrm{mg} / \mathrm{m}^{2} ; 6$ cycles & 2002 \\
\hline $\begin{array}{l}\text { CHOP (doxorubicin } \\
\text { cyclophosphamide, vincristine and } \\
\text { prednisone) }\end{array}$ & $\begin{array}{l}\text { doxorubicin } 25 \mathrm{mg} / \mathrm{m}^{2}, \text { cyclophosphamide } \\
300 \mathrm{mg} / \mathrm{m}^{2}, \text { vincristine } 1 \mathrm{mg} / \mathrm{m}^{2} \text { and } \\
\text { prednisone } 40 \mathrm{mg} / \mathrm{m}^{2} ; 3 \text { cycles in total }\end{array}$ & 2003 \\
\hline Alemtuzumab (Campath-1H) & $30 \mathrm{mg} ; 20$ applications in total & 2004 \\
\hline Fludarabine & $30 \mathrm{mg} / \mathrm{m}^{2}$ & $2004 / d-9$ to $d-5$ \\
\hline Busulfan & $4 \times 1 \mathrm{mg} / \mathrm{kg}$ & $2004 / d-4$ to $d-3$ \\
\hline Alemtuzumab (Campath-1H) & $\begin{array}{l}5 \mathrm{mg} \\
10 \mathrm{mg} \\
20 \mathrm{mg}\end{array}$ & $\begin{array}{l}2004 / d-9 \\
2004 / d-8 \\
2004 / d-7 \text { to } d-5\end{array}$ \\
\hline Prednisolone & $\begin{array}{l}50 \mathrm{mg} \\
80 \mathrm{mg} \text { tapered to } 30 \mathrm{mg} \text { over } 2 \text { months } \\
80 \mathrm{mg} \\
80 \mathrm{mg} \text { tapered to } 20 \mathrm{mg}\end{array}$ & $\begin{array}{l}2004 / d-9 \text { to } d-5 \\
2004 / 1+20 \\
2004 / d+136 \text { to } d+183 \\
2004 / d+184\end{array}$ \\
\hline Cyclosporin A & $\begin{array}{l}2 \times 150 \mathrm{mg} \\
2 \times 175 \mathrm{mg} \\
2 \times 200 \mathrm{mg} \\
1 \times 200 / 225 \mathrm{mg} \\
2 \times 200 \mathrm{mg} \\
2 \times 150 \mathrm{mg}\end{array}$ & $\begin{array}{l}2004 / d-1 \text { to } d+1 \\
2004 / d+2 \text { to } d+3 \\
2004 / d+4 \text { to } d+5 \\
2004 / d+6 \text { to } d+11 \\
2004 / d+12 \\
2004 / d+13 \text { to } d+19\end{array}$ \\
\hline Tacrolimus & $2 \times 1 \mathrm{mg}$ & $2004 / d+19$ \\
\hline Cidofovir & $5 \mathrm{mg} / \mathrm{kg}$, once per week & $2004 / d+173$ and $d+180$ \\
\hline Probenicid & $\begin{array}{l}2 \mathrm{~g}, 3 \mathrm{~h} \text { before CDV application; } \\
1 \mathrm{~g}, 2 \text { and } 8 \mathrm{~h} \text { thereafter }\end{array}$ & $2004 / d+173$ and $d+180$ \\
\hline Chlorpromazine & $\begin{array}{l}3 \times 200 \mathrm{mg} \\
3 \times 400 \mathrm{mg} \\
3 \times 200 \mathrm{mg} \\
3 \times 400 \mathrm{mg} \\
3 \times 200 \mathrm{mg}\end{array}$ & $\begin{array}{l}2004 / d+173 \\
2004 / d+174 \text { to } d+186 \\
2004 / d+187 \text { to } d+198 \\
2004 / d+199 \text { to } d+201 \\
2004 / d+202\end{array}$ \\
\hline
\end{tabular}

${ }^{1}$ The posology corresponds to the dose per day, except for cidofovir which is administered weekly.

${ }^{2}$ The days before (d-) and after $(\mathrm{d}+)$ stem cell transplantation (SCT) are shown.

Four months after transplant, a relapse of skin GvHD required repeated steroid treatment with prednisolone. Two weeks later the patient complained of drowsiness, vertigo, slight tremor and erratic mood swings which worsened during the next days. Clinical examination revealed bilateral homonymous hemianopsia of his right field of vision. A brain magnetic resonance imaging (MRI) showed an area of demyelination in the left occipital lobe of the brain (fig. 1b, left panel). No typical signs of infarction or tumor were detected.
Biochemical analysis of the cerebrospinal fluid (CSF) revealed signs of nonspecific inflammation, with mild lymphocytic pleocytosis (18 megaparticles/l, normal $<5$ megaparticles/l) and a slight increase in glucose $(8.07$ $\mathrm{mmol} / \mathrm{l}$, normal $2.8-4.4 \mathrm{mmol} / \mathrm{l})$, total protein $(639 \mathrm{mg} / \mathrm{l}$, normal $130-400 \mathrm{mg} / \mathrm{l})$ and lactate $(3.18 \mathrm{mmol} / \mathrm{l}$, normal $1.2-2.1 \mathrm{mmol} / \mathrm{l})$. In addition, neither bacterial nor fungal DNA was detectable in CSF by PCR, nor were neurotropic viruses (herpes simplex $1 / 2$, varicella-zoster virus, cytomegalovirus, Epstein-Barr virus, human herpes virus 
Fig. 1. Diagnosis and evolution of progressive multifocal encephalopathy under therapy. a Dynamics of the JC virus (JCV) load in the plasma and cerebrospinal fluid (CSF) of the patient under cidofovir therapy. The viral load in the plasma (left panel) and cerebrospinal fluid (right panel) of the patient was determined by real-time PCR. The viral load represents the mean and standard error of 3 independent measures. Onset of the symptoms and cidofovir administration as indicated. b Magnetic resonance imaging (MRI) of the brain. Axial brain MRI in FLAIR sequences. Left: demyelinating lesion of high signal intensity in the left occipital lobe, paraventricular to the lateral ventricle. Right: demyelinating lesion of high signal intensity, progressive in size, encompassing both the left occipital and temporal lobe. New subcortical lesion of high signal intensity is located in the right occipital lobe.
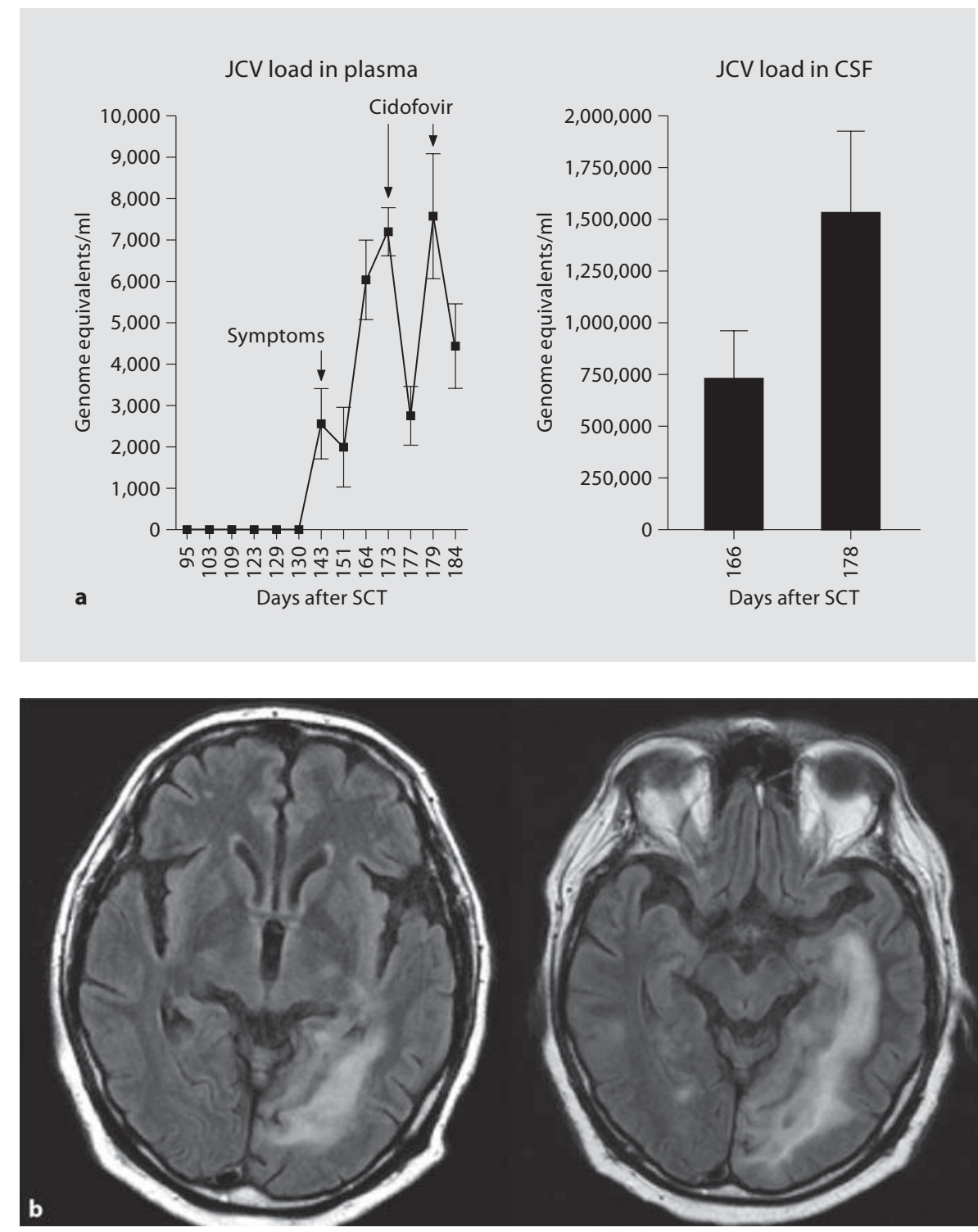

6/8, adeno- and enterovirus) except for JC virus (JCV). JC viral load was determined in both CSF and peripheral blood by real-time PCR using 2 different protocols $[1,2]$. Mean values for CSF and peripheral blood were $7.3 \times 10^{5}$ and $7.2 \times 10^{3}$ copies $/ \mathrm{ml}$, respectively, indicating systemic infection (fig. 1a). Antiviral treatment including cidofovir (CDV) with concomitant probenicid, chlorpromazine and immunoglobulins was initiated (table 1). A follow-up brain MRI 2 weeks after therapy initiation evidenced multiple areas of demyelination (fig. 1b, right panel). The JC viral load in CSF and peripheral blood showed no significant decrease despite antiviral treatment (fig. 1a). The disease progressed to blindness, deaf- ness and disorientation as well as fecal and urinary incontinence. The patient died from progressive multifocal leukoencephalopathy (PML) 8 months following transplant and 3 months after onset of the first neurological symptoms.

\section{Discussion}

We report on an HIV-negative patient diagnosed with PML following allogeneic SCT and immunosuppressive treatment (table 1), in whom JC viral load was monitored in plasma and CSF under anti-JCV-specific therapy. In 
the course of 2-fold CDV application, a $40-60 \%$ decrease in JC viral load in plasma samples was observed shortly after drug administration (fig. la, left panel), whereas JC viral load in CSF samples in fact doubled (mean values: $7.3 \times 10^{5}$ vs. $1.5 \times 10^{6}$ genome equivalents $/ \mathrm{ml}$; fig. $1 \mathrm{a}$, right panel). According to our observations, combined anti-JCV-specific therapy with CDV and chlorpromazine was ineffective in significantly lowering JCV plasma and CSF loads and thus providing a clinical benefit for our patient. In this context, possible mechanisms for the nonresponse of the anti-JCV-specific therapy are discussed.

PML is a subacute demyelinating disease of the central nervous system (CNS) with a grim prognosis [3] caused by the neurotropic virus JC, a double-stranded DNA virus of the Polyomaviridae family. In immunocompromised patients, reactivation of JCV leads to various symptoms ranging from acute febrile illness to PML [4]. So far, various treatment regimens have been discussed. They mainly consist of 2 therapeutic approaches: inhibition of viral replication in the host cell, and a most novel approach based on inhibition of virus entry into host cells.

The first therapeutic approach is based upon inhibition of viral replication in host cells by using drugs with antiviral activity against Polyomaviridae, such as CDV and cytosine arabinoside $[5,6]$. CDV is a deoxycytidine monophosphate analogue, with broad in vitro and in vivo activity against DNA viruses of various families (Adenoviridae, Herpesviridae and Polyomaviridae) [5, 6]. In vitro studies showed that CDV inhibits replication of mouse polyomavirus and Simian virus 40 [5], and displays efficacy against JCV multiplication in persistently infected human fetal brain cell lines [7]. A scarce number of anecdotal reports describe possible benefits of CDV treatment in PML, specifically in HIV-negative CLL patients suffering from PML $[8,9]$.

However, it remains unclear whether the improvements of symptoms in those patients is the net result of the antiviral effects of CDV, or of the immune reconstitution that follows successful cytostatic CLL therapy. Of note, intravenous administration of CDV does not yield detectable CSF concentrations $(<0.1 \mathrm{mg} / \mathrm{ml}$, assay detection threshold, data from Gilead Sciences Inc.), indicating that $\mathrm{CDV}$ does not diffuse through the blood-brain barrier. $\mathrm{Q}_{\text {albumin }}$ (concentration of albumin in CSF/concentration of albumin in plasma) was normal in our patient, excluding a substantial CNS barrier dysfunction. However, small leaks in the blood-brain barrier allowing CDV to enter the CNS cannot be completely ruled out in PML despite normal $Q_{\text {albumin. }}$. Whether sufficient CSF drug levels for inhibition of viral replication are reached is an open question. Due to limited specimens, intrathecal levels of CDV and its metabolites could not be measured in our case. In view of the rising JC viral load in CSF and disease progression despite CDV therapy, intrathecal drug concentrations may not have reached sufficiently high levels to display antiviral effects, thus contributing to treatment failure.

The second and novel therapeutic approach relies on the use of neurotropic drugs to inhibit JCV entry into the host cell and subsequent viral spread. The rationale for this approach is based on the observation that the serotonergic receptor 5HT2A acts as the cellular receptor for JCV on human glial cells [10]. 5HT2A receptor antagonists like chlorpromazine and clozapine effectively inhibit JCV infection of glial cells and the spread of JCV through tissues, by blocking the clathrin-dependent endocytosis that enables cellular JCV uptake [11]. However, the clinical efficacy of this drug class in treating PML has not been evaluated yet. In our case, progress of the demyelinating lesions was evidenced by brain MRI 2 weeks after initiation of the treatment, indicating that JCV spread within the white matter of the brain could not be impeded by chlorpromazine (fig. $1 \mathrm{~b}$, right panel). The continuous development of new brain foci as shown in our patient by MRI (fig. 1b, right panel) is concordant with a lytic infection including viral spread from cell to cell and high quantities of tissue-associated virus. Chlorpromazine interference with 5HT2A receptor-mediated clathrin-dependent endocytosis targets an early step in the viral life cycle. Drug application early in the course of the disease may thus be crucial to achieve a clinical benefit, as glial cells already harboring/having internalized the virus are left unaffected by chlorpromazine [11]. Furthermore, overall viral mass in tissue may constitute a critical factor as both virus particles and chlorpromazine compete for the same cell receptor. Newer atypical antipsychotics with less adverse effects, like risperidone or olanzapine, have proven to be significantly more potent 5HT2A receptor antagonists in vitro than chlorpromazine or clozapine [12], which may render them more ideal candidates for the treatment and/or prophylaxis of PML in immunodeficient patients.

Cell-mediated immunity is essential in the control of many viral infections in humans and has also been suggested to play a crucial role in the containment of JCV [13-15]. Therefore, it is likely that immunosuppressant drugs not only trigger JCV reactivation in immunocompromised patients but sustainably influence the course and prognosis of PML. Infectious complications associated with calcineurin inhibitors, for example cyclosporin 
A and tacrolimus, include other viral infections [16] of which $B K$ virus reactivation represents a significant cause of allograft failure in renal transplant recipients [17]. Furthermore, cyclosporin A has been associated with the occurrence of PML in patients suffering from rheumatic diseases [18, 19]. The development of PML has also been observed in patients receiving corticosteroids for rheumatic disease [20-24]. A correlation between JC viruria and corticosteroid treatment has been demonstrated in one study [25]. Purine nucleoside analogues, primarily FAMP, inducing a rapid T lymphocyte decline render recipients particularly prone to various opportunistic infections [26] and have also been linked to the development of PML [9, 27-29]. Alemtuzumab, used as consolidation therapy in CLL patients, in preparation for SCT, or to avert acute and chronic GvHD, provokes increased vulnerability to infections due to profound and sustained lymphocyte depletion [30] as demonstrated by several clinical trials [31-33]. Polyomavirus - that is BK virus infections have been described in renal transplant recipients [34], whereas JCV reactivation after administration of alemtuzumab has not been reported so far in the lit- erature. Considering the immune-modulating therapy regimens given to our patient (table 1), it is conceivable that the underlying immunosuppression may account for the nonresponse of the anti-JCV-specific therapy by countervailing the antiviral effects of CDV and chlorpromazine.

In conclusion, the use of 5HT2A receptor antagonists like chlorpromazine in addition to CDV may represent, if administered early in the course of the disease or given prophylactically, a possible strategy for treatment/prevention of PML. Further studies providing both experimental and clinical data are needed to evaluate the benefit of this strategy for treatment and/or prophylaxis of PML.

\section{Acknowledgements}

We are grateful to Benedikt Weissbrich for his support during the initial phase of this study. We acknowledge Kristin Hille's excellent technical support, and Michael Schubert for editorial help.

\section{References}

1 Ryschkewitsch C, Jensen P, Hou J, Fahle G, Fischer S, Major EO: Comparison of PCRsouthern hybridization and quantitative real-time PCR for the detection of JC and BK viral nucleotide sequences in urine and cerebrospinal fluid. J Virol Methods 2004;121: 217-221.

2 Watzinger F, Suda M, Preuner S, Baumgartinger R, Ebner K, Baskova L, Niesters HG, Lawitschka A, Lion T: Real-time quantitative PCR assays for detection and monitoring of pathogenic human viruses in immunosuppressed pediatric patients. J Clin Microbiol 2004;42:5189-198.

3 Berger JR, Levy RM, Flomenhoft D, Dobbs M: Predictive factors for prolonged survival in acquired immunodeficiency syndromeassociated progressive multifocal leukoencephalopathy. Ann Neurol 1998;44:341-349.

4 Reiss K, Khalili K: Viruses and cancer: lessons from the human polyomavirus, JCV. Oncogene 2003;22:6517-6523.

5 Andrei G, Snoeck R, Vandeputte M, De Clercq E: Activities of various compounds against murine and primate polyomaviruses. Antimicrob Agents Chemother 1997;41: 587-593.

6 De Clercq E: Therapeutic potential of cidofovir (HPMPC, Vistide) for the treatment of DNA virus (i.e. herpes-, papova-, poxand adenovirus) infections. Verh K Acad Geneeskd Belg 1996;58:19-47; discussion 47-49.
7 Hou J, Major EO: The efficacy of nucleoside analogs against JC virus multiplication in a persistently infected human fetal brain cell line. J Neurovirol 1998;4:451-456.

8 Viallard JF, Lazaro E, Lafon ME, Pellegrin JL: Successful cidofovir therapy of progressive multifocal leukoencephalopathy preceding angioimmunoblastic T237 cell lymphoma. Leuk Lymphoma 2005;46:16591662.

9 Cid J, Revilla M, Cervera A, Cervantes F, Munoz E, Ferrer I, Montserrat E: Progressive multifocal leukoencephalopathy following oral fludarabine treatment of chronic lymphocytic leukemia. Ann Hematol 2000;79: 392-395.

10 Elphick GF, Querbes W, Jordan JA, Gee GV, Eash S, Manley K, Dugan A, Stanifer M, Bhatnagar A, Kroeze WK, Roth BL, Atwood WJ: The human polyomavirus, JCV, uses serotonin receptors to infect cells. Science 2004;306:1380-1383.

11 Pho MT, Ashok A, Atwood WJ: JC virus enters human glial cells by clathrin-dependent receptor-mediated endocytosis. J Virol 2000; 74:2288-2292.

12 Altschuler EL, Kast RE: The atypical antipsychotic agents ziprasidone, risperdone and olanzapine as treatment for and prophylaxis against progressive multifocal leukoencephalopathy. Med Hypotheses 2005;65:585586.
13 Koralnik IJ, Du Pasquier RA, Kuroda MJ, Schmitz JE, Dang X, Zheng Y, Lifton M, Letvin NL: Association of prolonged survival in HLA-A2+ progressive multifocal leukoencephalopathy patients with a CTL response specific for a commonly recognized JC virus epitope. J Immunol 2002;168:499-504.

14 Du Pasquier RA, Kuroda MJ, Zheng Y, JeanJacques J, Letvin NL, Koralnik IJ: A prospective study demonstrates an association between JC virus-specific cytotoxic T lymphocytes and the early control of progressive multifocal leukoencephalopathy. Brain 2004;127:1970-1978.

15 Gasnault J, Kahraman M, de Goer de Herve MG, Durali D, Delfraissy JF, Taoufik Y: Critical role of JC virus-specific CD4 T-cell responses in preventing progressive multifocal leukoencephalopathy. AIDS 2003;17:14431449.

16 Singh N: Infectious complications in organ transplant recipients with the use of calcineurin-inhibitor agent-based immunosuppressive regimens. Curr Opin Infect Dis 2005; 18:342-345.

17 Hirsch HH: Polyomavirus BK nephropathy: a (re-)emerging complication in renal transplantation. Am J Transplant 2002;2:25-30. 
18 Ettinger J, Feiden W, Hubner G, Schreiner M: Progressive multifocal leukoencephalopathy in Wegener's granulomatosis in relation to therapy with cyclosporin A (in German). Klin Wochenschr 1989;67:260-264.

19 Gentile S, Sacerdote I, Roccatello D, Giordana MT: Progressive multifocal leukoencephalopathy during cyclosporine treatment: a case report. Ital J Neurol Sci 1996;17: 363-366.

20 Newton P, Aldridge RD, Lessells AM, Best PV: Progressive multifocal leukoencephalopathy complicating systemic lupus erythematosus. Arthritis Rheum 1986;29:337-343.

21 Itoh K, Kano T, Nagashio C, Mimori A, Kinoshita M, Sumiya M: Progressive multifocal leukoencephalopathy in patients with systemic lupus erythematosus. Arthritis Rheum 2006;54:1020-1022.

22 Sponzilli EE, Smith JK, Malamud N, McCulloch JR: Progressive multifocal leukoencephalopathy: a complication of immunosuppressive treatment. Neurology $1975 ; 25$ : 664-668.

23 Morgenstern LB, Pardo CA: Progressive multifocal leukoencephalopathy complicating treatment for Wegener's granulomatosis. J Rheumatol 1995;22:1593-1595.

24 Warnatz K, Peter HH, Schumacher M, Wiese L, Prasse A, Petschner F, Vaith P, Volk B, Weiner SM: Infectious CNS disease as a differential diagnosis in systemic rheumatic diseases: three case reports and a review of the literature. Ann Rheum Dis 2003;62:5057.
25 Wang M, Tsai RT, Ou WC, Lin CK, Tsay GJ, Chang H, Chang D: Treatment with cytotoxic immunosuppression agents increases urinary excretion of JCV in patients with autoimmune disease. J Med Virol 2000;62: 505-510.

26 Anaissie EJ, Kontoyiannis DP, O'Brien S, Kantarjian H, Robertson L, Lerner S, Keating MJ: Infections in patients with chronic lymphocytic leukemia treated with fludarabine. Ann Intern Med 1998;129:559-566.

27 Kiewe P, Seyfert S, Korper S, Rieger K, Thiel E, Knauf W: Progressive multifocal leukoencephalopathy with detection of JC virus in a patient with chronic lymphocytic leukemia parallel to onset of fludarabine therapy. Leuk Lymphoma 2003;44:1815-18.

28 Saumoy M, Castells G, Escoda L, Mares R, Richart C, Ugarriza A: Progressive multifocal leukoencephalopathy in chronic lymphocytic leukemia after treatment with fludarabine. Leuk Lymphoma 2002;43:433436.

29 Vidarsson B, Mosher DF, Salamat MS, Isaksson HJ, Onundarson PT: Progressive multifocal leukoencephalopathy after fludarabine therapy for low-grade lymphoproliferative disease. Am J Hematol 2002;70:51-54.

30 Knechtle SJ, Pirsch JD, H. Fechner JJ, Becker BN, Friedl A, Colvin RB, Lebeck LK, Chin LT, Becker YT, Odorico JS, D'Alessandro AM, Kalayoglu M, Hamawy MM, Hu H, Bloom DD, Sollinger HW: Campath-1H induction plus rapamycin monotherapy for renal transplantation: results of a pilot study. Am J Transplant 2003;3:722-730.
31 Keating MJ, Flinn I, Jain V, Binet JL, Hillmen P, Byrd J, Albitar M, Brettman L, Santabarbara P, Wacker B, Rai KR: Therapeutic role of alemtuzumab (Campath-1H) in patients who have failed fludarabine: results of a large international study. Blood 2002;99:35543561.

32 Rai KR, Freter CE, Mercier RJ, Cooper MR, Mitchell BS, Stadtmauer EA, Santabarbara P, Wacker B, Brettman L: Alemtuzumab in previously treated chronic lymphocytic leukemia patients who also had received fludarabine. J Clin Oncol 2002;20:3891-3897.

33 Lundin J, Kimby E, Bjorkholm M, Broliden PA, Celsing F, Hjalmar V, Mollgard L, Rebello P, Hale G, Waldmann H, Mellstedt H, Osterborg A: Phase II trial of subcutaneous anti-CD52 monoclonal antibody alemtuzumab (Campath-1H) as first-line treatment for patients with B-cell chronic lymphocytic leukemia (B322 CLL). Blood 2002;100:768773.

34 Peleg AY, Husain S, Kwak EJ, Silveira FP, Ndirangu M, Tran J, Shutt KA, Shapiro R, Thai N, Abu-Elmagd K, McCurry KR, Mar$\cos$ A, Paterson DL: Opportunistic infections in 547 organ transplant recipients receiving alemtuzumab, a humanized monoclonal CD-52 antibody. Clin Infect Dis 2007; 44:204-212. 